\title{
Mycosphere Essays 9: Defining biotrophs and hemibiotrophs
}

\author{
De Silva NI ${ }^{1,2,3,4}$, Lumyong $\mathrm{S}^{1}$, Hyde $\mathrm{KD}^{2}$, Bulgakov $\mathrm{T}^{5}$, Phillips $\mathrm{AJL}^{6}$ and Yan \\ $\mathrm{JY}^{7}$
}

${ }^{1}$ Department of Biology, Faculty of Science, Chiang Mai University, Chiang Mai, 50200 Thailand

${ }^{2}$ Center of Excellence in Fungal Research, Mae Fah Luang University, Chiang Rai, 57100 Thailand

${ }^{3}$ World Agro forestry Centre East and Central Asia Office, 132 Lanhei Road, Kunming, 650201, China

${ }^{4}$ Key Laboratory for Plant Biodiversity and Biogeography of East Asia (KLPB), Kunming Institute of Botany, Chinese Academy of Science, Kunming 650201, Yunnan China

${ }^{5}$ Academy of Biology and Biotechnology, Southern Federal University, Rostov-on-Don 344090, Russia

${ }^{6}$ University of Lisbon, Faculty of Sciences, Biosystems and Integrative Sciences Institute (BioISI), Campo Grande, 1749-016 Lisbon, Portugal

${ }^{7}$ Institute of Plant and Environment Protection, Beijing Academy of Agriculture and Forestry Sciences, Beijing 100097, People's Republic of China

De Silva NI, Lumyong S, Hyde KD, Bulgakov T, Phillips AJL, Yan JY 2016 - Mycosphere Essays 9: Defining biotrophs and hemibiotrophs. Mycosphere 7(5), 545-559, Doi 10.5943/mycosphere/7/5/2

\begin{abstract}
Fungi are ubiquitous and exhibit diverse life-styles. Many exhibit a continuum of life-styles ranging from biotrophy, through to necrotrophy and ultimately to saprotrophy. This paper was initiated to establish a set of definitions for fungal life-styles, in an attempt to achieve better documentation in scientific publications of the roles played by taxa. Biotrophism is a life-style where a taxon shows high dependency on a host plant, but causes minimum damage. Biotrophs have total dependency upon living plant cells, whereas hemibiotrophs have an initial biotrophic life-style and a subsequent necrotrophic phase. The necrotrophic life-style involves actively killing host plant cells by secreting cell wall degrading enzymes and phytotoxins. Biotrophic fungi have developed an intimate relationship with the host plant using haustoria for nutrient assimilation. It is believed that biotrophy evolved when fungi developed an ability to modulate plant defense mechanisms. Therefore, biotrophs utilize different strategies to overcome host plant defenses. This paper defines the terms biotrophs and hemibiotrophs in relation to fungi and provides a discussion on its significance, role and life history.
\end{abstract}

Key words - appressoria - endophyte - haustorium - necrotroph - saprotroph

\section{Introduction}

The term biotroph is used in many areas of mycology and yet there is no clear definition for this terminology (Box 1). This paper was initiated to aid mycologists to describe the life-styles of fungi when introducing new species, or discussing the roles of various groups of fungi. For example, Barr (1987) and Hyde et al. (2013) list the various life-styles of Dothideomycetes as endophytes, epiphytes, fungicolous, biotrophs, hemibiotrophs and saprobes. Hyde et al (2013) also list species of Capnodiales as leaf epiphytes, species of Lichenoconiales as lichenicolous fungi and species of Microthyriales as foliar epiphytes, biotrophs, and saprobes. Ariyawansa et al. (2015) and Liu et al. (2015) provided notes on different fungal taxa. Ariyawansa et al. (2015) introduced 
Alternaria murispora as saprobes and Liu et al. (2015) introduced genera Amphibambusa, Flammeascoma and Chaetocapnodium as saprobes.

\section{Biotrophs}

'Obligate parasites growing on another organism, in an intimate association with its cytoplasm' (The Dictionary of the Fungi 2001)

'Fungi that grow and reproduce in living plant tissue while obtaining nutrients through intimate interactions with living plant cells' (Latijnhouwers et al. 2003)

'Fungi that have total dependency on the host to complete their life-cycle, deriving nutrients from living host cells by differentiation of specialized infection structures called haustoria' (Divon \& Fluhr 2006)

'Pathogens that specialize to feed on living plant tissues and some have developed an intimate relationship with their host plant' (de Wit 2007)

'Fungi that do not kill their hosts and require living cells for growth, co-opt homeostasis in the host to create an advantage for the fungus' (Dickman \& de Figueiredo 2011)

'Parasites that derive energy from living cells and are obligate parasites meaning they cannot live without their host, possess haustoria, do not secrete abundant lytic enzymes and cause little damage to the host plant' (Kemen \& Jones 2012)

'Pathogens that derive nutrients from live host cells and produce effectors to suppress the basal plant defense. They form appressoria to infect epidermal cells produce cell wall degrading enzymes, hyphae to draw the nutrients, and sporulate without killing the host cells' (Pandey et al. 2016)

\section{Hemibiotrophs}

'Fungi that initially establish a biotrophic relationship with their host but subsequently, the host cells die as the infection proceeds' (Latijnhouwers et al. 2003)

'Fungi that initially form an association with living cells of the host, much like a biotroph, and then in the later stages of infection they become necrotrophic, actively killing host cells' (Plant Pathology Glossary 2003)

'Fungi having an initial period of biotrophy followed by necrotrophic hyphae' (Oliver \& Ipcho 2004)

'Fungi that render its host largely alive while establishing itself within the host tissue with brief biotrophic-like phase and later switching to a necrotrophic life-style' (Divon \& Fluhr 2006)

'Fungi that are parasitic in living tissue for some time and then continues to live in dead tissue' (Wiktionary 2016)

\section{Necrotrophs}

'Pathogens that kill and feed off the dead tissue. All true necrotrophic pathogens initially have a biotrophic phase in which they asymptomatically colonize the host tissues' (Spanu et al. 2012)

'Pathogens that cause rapid cell death in hosts and elicit major molecular responses from the plant. They have wide host ranges and secrete copious amounts of lytic enzymes and toxins' (Meinhardt et al. 2014)

\section{Endophytes}

'All organisms inhabiting plant organs that at some time in their life can colonize internal plant tissues without causing apparent harm to the host' (Hyde \& Soytong 2008)

\section{Saprotrophs}

'Microbes that feed on tissues that are already dead and decaying' (Spanu et al. 2012)

\section{Box 1. Definitions of various fungal life-styles}



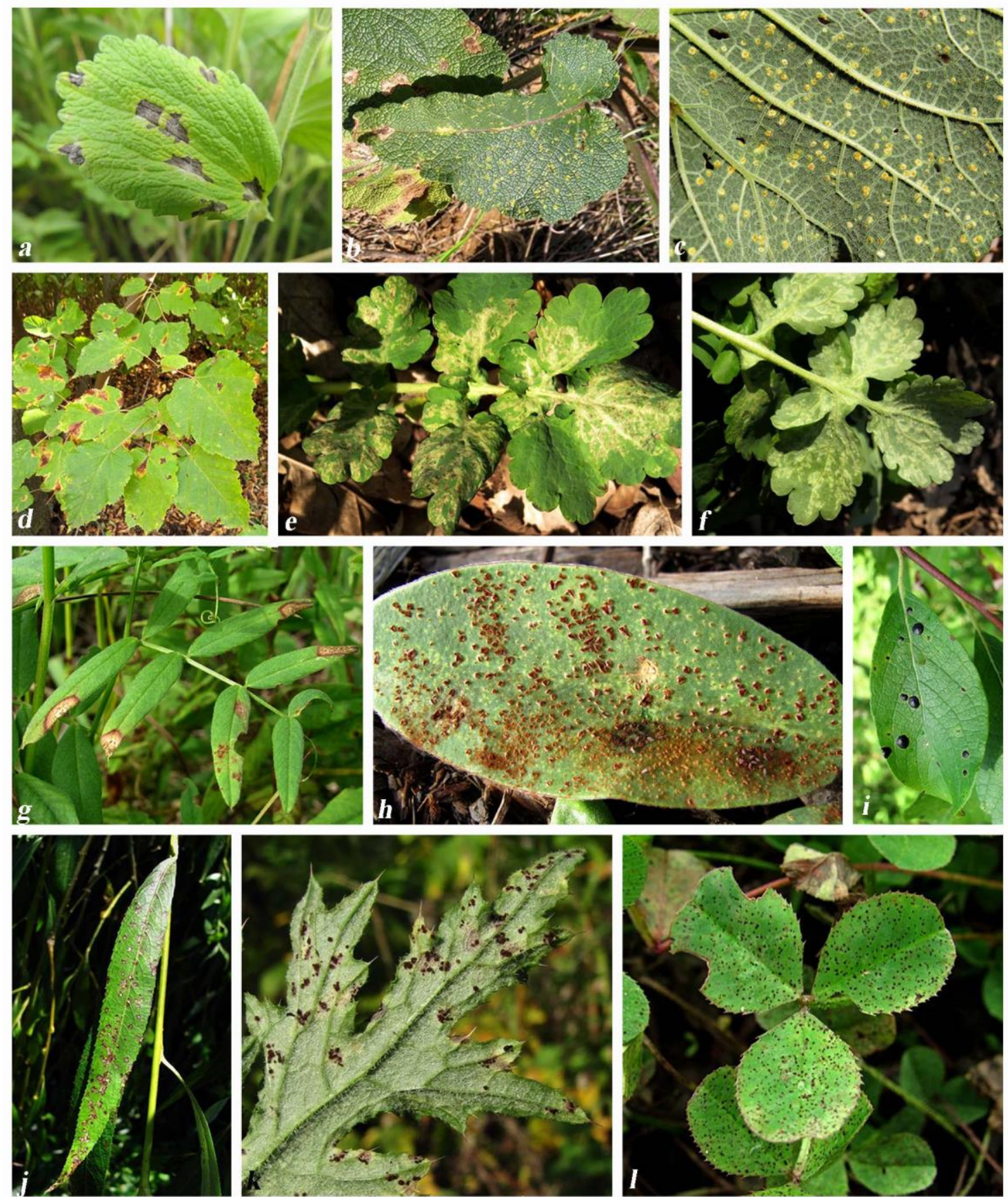

Fig. 1 - Biotrophic and hemibiotrophic fungi on leaves of different host species. a. Biotroph Peronospora lamii on Marrubium praecox. b. Biotroph - Puccinia stipina on Salvia nutans. c. Biotroph - Puccinia stipina on Salvia nutans (lower side of the leaf). d. Biotroph - Taphrina polyspermum on Acer tataricum. e. Biotroph - Peronospora chelidonii on Chelidonium majus. $\mathrm{f}$. Biotroph - Peronospora chelidonii on Chelidonium majus (lower side of the leaf). g. Hemibiotroph on Vicia sepium. h. Hemibiotroph on Anthylis vulneraria. i. Hemibiotroph on Salix caprea. j. Hemibiotroph on Salix babylonica. k. Hemibiotroph on Carduus crispus. 1. Hemibiotroph on Trifolium repens. Photo credit: Timur Bulgakov

Fungi have different mechanisms that enable infection and colonization of host plant tissues with modifications of nutrient assimilation and various modes of interaction with their host (Harrison 1999, Mendgen \& Hahn 2002, Dickman \& de Figueiredo 2011, Kemen \& Jones 2012, Meinhardtet al. 2014, Petriacq et al. 2016). Classification of trophic groups of fungi is generally based on nutrient assimilation (living vs. dead cells), ability to infect young, healthy tissues or older, senescent tissues and types of defense mechanism (jasmonate vs. salicylic acid pathway) 
used against the host plant (Oliver \& Ipcho 2004, Delaye et al. 2013, Petriacq et al. 2016). For comparison we list the definitions that have been used in the literature for life-styles (Box 1). It is important to identify the fungal life-style, whether it is a pathogen, saprobe or initial biotroph that changes to a necrotroph. It is however, difficult to draw boundaries to separate fungal life-styles as most maintain a continuum from biotrophy, through to necrotrophy and / or saprotrophy.

We provide a scheme of definitions for various fungal life-style terms (Box 2) in an attempt to achieve better data to describe roles in taxonomic papers. It is important to state a fungal lifestyle in a species description because it gives insight into the nutritional and ecological significance of that particular fungus. Different authors have introduced various boundaries for classifying fungal life-styles. Here we introduce a scheme considering most of the earlier definitions and some new ideas. If followed, this will help authors to use a standardized system for naming fungal lifestyles when introducing a new species.

\section{Biotrophs}

Fungi that depend upon a narrow host range while deriving nutrients from living host cells. They grow on living plant tissues and cause damage to the host tissue. They produce special structures such as haustoria and appressoria for nutrient acquisition and penetration of the host plant.

\section{Hemibiotrophs}

Fungi that have a narrow host range and initial biotrophic life-style associated with living host cells and later switch to a necrotrophic life style that kill host cells to obtain nutrients. Most taxa produce haustoria and appressoria during the initial biotrophic phase. They synthesize hydrolytic enzymes and toxins during the later necrotrophic phase.

\section{Necrotrophs}

Fungi that cause host cell death in a wide range of host plants by secreting hydrolytic enzymes and toxins, and obtain nutrients from the dead cells.

\section{Saprotrophs}

Fungi that grow on dead plant tissues and absorb nutrients from the dead cells by secreting hydrolytic enzymes.

\section{Endophytes}

Fungi that reside inside host tissues for all or part of their life cycle without causing visible symptoms on the host plant.

\section{Box 2. Suggested scheme of definitions for fungal life-styles}

\section{What are biotrophs versus hemibiotrophs - the definitions?}

The term biotroph expresses a unique life-style, which enables fungi to derive energy from living plant cells (through oxidation of carbonic compounds obtained from the host) and have a total dependency on the host plant to complete their life cycle. The biotroph causes damage to the host plant and has special structures such as appressoria and haustoria for penetration and nutrient acquisition from a narrow host range (Mendgen \& Hahn 2002, Oliver \& Ipcho 2004, Divon \& Fluhr 2006, de Wit 2007, Delaye et al. 2013, Pandey et al. 2016). Different definitions have been recorded for biotrophs (Box 1). Generally biotrophs include the rusts, the powdery mildew pathogens, the oomycete agents (white rusts and downy mildews) as obligate biotrophs and the smuts (Latijnhouwers et al. 2003, Spanu et al. 2012). The term 'obligate biotrophs' refers to total dependency upon the host and they cannot generally be cultured on artificial media (Latijnhouwers et al. 2003). Different examples of fungi and oomycetes as biotrophs and with other life-styles are tabulated (Table 1). 
Table 1 Examples of fungi with different life-styles

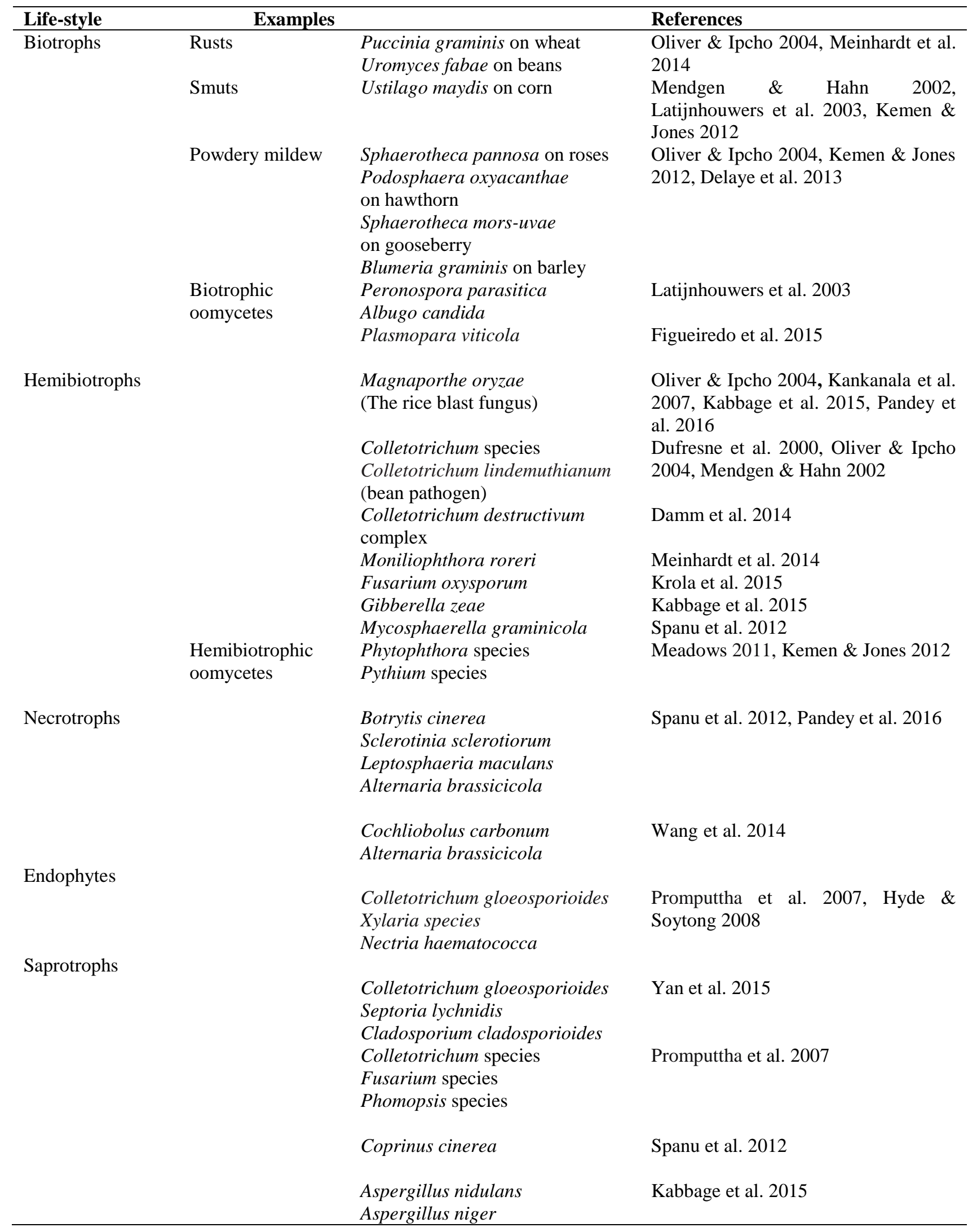

Some fungi exhibit more than one life-style. They may initially be biotrophic, but later change to a necrotrophic life-style (Plant Pathology Glossary 2003, Oliver \& Ipcho 2004, Divon \& Fluhr 2006). These can be termed hemibiotrophs. Hemibiotrophs are defined as 'fungi that initially form an association with living cells of the host, much like a biotroph, and then in the later stages 
of infection they become necrotrophic ('fungi that cause the death of the host tissues as it grows through, obtaining its energy from the dead cells')' (Oliver \& Ipcho 2004). Some other definitions for hemibiotrophs have been used (Box 1). The rice blast fungus Magnaporthe oryzae (Kankanala et al. 2007) and Colletotrichum species are generally considered to be hemibiotrophs (Mendgen \& Hahn 2002, Latijnhouwers et al. 2003, Dada \& Lucas 2007). Damm et al. (2014) listed three hemibiotrophic species, Colletotrichum pisicola, $C$. vignae and $C$. destructivum that belong to the Colletotrichum destructivum complex. Fusarium oxysporum the cause of fusarium wilt disease and Moniliophthora roreri, which causes frosty pod rot disease of cacao, are hemibiotrophs that affect many agricultural and floricultural crops worldwide (Meinhardt et al. 2014, Krola et al. 2015).

Endophytes with biotrophic life-styles can be found in almost every living plant (Petrini et al. 1992, Porras-Alfaro \& Bayman 2011, Spanu et al. 2012, Delaye et al. 2013, Yan et al. 2015). An endophytic fungus is a 'fungus that lives inside plant tissues without showing external signs of infection' (Hyde \& Soytong 2008, Kemen \& Jones 2012). In general there are two main groups of endophytes, the clavicipitaceous and the non-clavicipitaceous endophytes. Clavicipitaceous endophytes, such as Neotyphodium species, are restricted to the family Poaceae and rely on their host throughout their life cycle (O'Hanlon et al. 2012, Hardoim et al. 2015). Non-clavicipitaceous endophytes (Fusarium sp., Colletotrichum sp., Phomopsis sp., and Xylaria sp.) occur in most terrestrial plants and can switch their life mode between pathogenic and saprobic when environmental conditions become unfavorable to the host (Petrini et al. 1992, Promputtha et al. 2005, 2007, Delaye et al. 2013).

Cankers and diebacks are destructive fungal diseases that cause ecological and economical losses. Grapevine canker diseases cause death of spurs, canes, cordons, trunks and eventual dieback of vines (Torres et al. 2009). Botryosphaeriaceae species (Lasiodiplodia theobromae, Neofusicoccum parvum), Pestalotiopsis species (Pestalotiopsis uvicola), Truncatella species and Diatrypaceae species, have been isolated from diseased grapevines in Texas (Torres et al. 2009). These fungi have been isolated as necrotrophs and some Botryosphaeriaceae species and Pestalotiopsis species have been reported as endophytes (Torres et al. 2009, Spagnolo et al. 2014). Botryosphaeria berengeriana is known to cause canker on apple in Japan (Xu et al. 2015). In addition, Diaporthe species and Colletotrichum species are able to cause cankers and diebacks in a wide variety of plants (Dissanayake et al. 2015, Yan et al. 2015). The Helotialean taxon, Hymenoscyphus pseudoalbidus, is the causative agent of ash dieback on Fraxinus excelsior and $F$. angustifolia in Europe (Gross et al. 2014). Hymenoscyphus pseudoalbidus causes necrotic lesions on leaves, twigs and stems, finally leading to wilting and dieback of shoots (Gross et al. 2014). The endophytic helotialean taxon, Cenangium ferruginosum is thought to switch to a pathogenic lifestyle under favourable conditions and causes pine dieback (Gross et al. 2014). Some fungi have been hypothesized to change their life-style from endophytic to necrotrophic and cause cankers and dieback. Pathogenicity studies need to provide strong evidence to confirm the potential hemibiotrophic nature of these fungi.

Scientists have classified a particular fungus under different life-styles. Oliver \& Ipcho (2004) classified the oomycete Phytophthora infestans, as having biotrophic, hemibiotrophic and necrotrophic life-styles. Mendgen \& Hahn (2002), Meadows (2011) and Petriacqet al. (2016) state that Phytophthora infestans is a hemibiotrophic oomycete, whereas Spanu et al. (2012) state that it is a necrotrophic oomycete. Another example is Cladosporium fulvum (the causal agent of tomato leaf mold), which Oliver \& Ipcho (2004) classify under biotrophic and hemibiotrophic life-styles. Sclerotina sclerotiorum is generally considered as a typical necrotroph. However, Kabbage et al. (2015) consider this fungus as hemibiotroph that may have a very short biotrophic phase when the fungus grows within the apoplastic space without crossing the plant cell wall during an initial, brief biotrophic life-style. The hyphae secrete oxalic acid and other pathogenicity factors that modulate host cell defense responses and then quickly switch to a necrotrophic life-style by killing cells via cell wall degrading enzymes. Further experiments are needed to study the relationship of a fungus and its host because it is difficult to draw boundaries between life-styles of fungi. 


\section{Relationships between biotrophs and host plants}

Biotrophs exhibit intimate relationships with their host plants (Both et al. 2005, de Wit 2007, Gao et al. 2010, Delaye et al. 2013). Generally, biotrophs such as rusts and powdery mildew pathogens are unable to grow in axenic cultures and complete their life cycles only on the living host (Parniske 2000, Both et al. 2005, Meadows 2011). They have limited ability to synthesize cell wall degrading enzymes (Kabbage et al. 2015). The barley powdery mildew Blumeria graminis has reduced production of carbohydrate active enzymes responsible for plant cell wall degradation (Spanu et al. 2010). Fungi also produce different secondary metabolites that act as pathogenicity factors. Polyketide synthases, modular nonribosomal peptide synthetases, terpene cyclases, and dimethylallyl diphosphate tryptophan synthases are some of the key enzymes involved in the biosynthesis of secondary metabolites in fungi. Only two enzymes are, however, recorded from Blumeria graminis namely polyketide synthases and modular nonribosomal peptide synthetases (Spanu et al. 2010). This suggests that biotrophs have lost many genes for pathogenesis. This might be vital to maintain long term interactions with living host plant cells, while avoiding detection of the fungus as a pathogen by the host plant (Micali et al. 2008, Kemen \& Jones 2012).

This extraordinary biological compatibility with the host is also thought to be due to a lack of genes that encode for enzymes and transporters needed for the biosynthesis of other certain metabolites (de Wit 2007, Meadows 2011, Kemen \& Jones 2012, Delaye et al. 2013, Guzman \& Heil 2014). The white rust fungus Albugo laibachii and downy mildew pathogen Hyaloperonospora arabidopsidis have lost the genes required for nitrogen and sulfur biosynthetic pathways (Meadows 2011). Powdery mildews, such as Blumeria species have lost the genes encoding enzymes for anaerobic fermentation (pyruvate decarboxylase, alcohol dehydrogenase), biosynthesis of glycerol from glycolytic intermediates and biosynthesis of nitrate and thiamine (Spanu et al. 2012). Spanu et al. (2010) state that barley powdery mildew, Blumeria graminis and two other powdery mildew species, Erysiphe pisi (pathogenic on Pisum sativum) and Golovinomyces orontii (pathogenic on Arabidopsis thaliana), lack genes encoding enzymes for primary and secondary metabolism, carbohydrate-active enzymes, and transporters. These missing genes are referred to as 'missing ascomycete core genes' because they are found in other ascomycetes. Experiments, however, revealed that the missing genes are expressed during the biotrophic phase of hemibiotrophic Colletotrichum higginsianum (Spanu et al. 2010). This suggests that the lack of 'missing ascomycete core genes' is essential for biotrophs such as powdery mildews, but not for hemibiotrophs.

Many biotrophs have evolved haustoria to obtain nutrients from living plant cells. Haustoria are differentiated hyphae forming sphaerical or lobed structures that penetrate the leaf mesophyl cell wall and grow adjacent to the plasma membrane, without entering the cytoplasm (Latijnhouwers et al. 2003, de Wit 2007, Kemen \& Jones 2012, Delaye et al. 2013, Kabbage et al. 2015). Both et al. (2005) stated that haustoria of Blumeria graminis (powdery mildew of barley) take up glucose from plant epidermal cells to synthesize glycogen during conidia formation. In addition, some biotrophs have extra-haustorial membranes that separate the haustorium from the plant cytoplasm (Latijnhouwers et al. 2003, Horbach et al. 2011, Kemen \& Jones 2012). This type of feeding behaviour is important for a nutrient rich micro-environment (nutrient sink) between the haustorium and the host cell membrane, to acquire essential nutrients from the cytoplasm (de Wit 2007, Delaye et al. 2013). Some endophytes such as Discula umbrinella and Rhabdocline parkeri however, produce haustoria during the early death of infected cells (Delaye et al. 2013). Haustoria production is essential for nutrient assimilation that ultimately leads to successful colonization and fungal fitness (Parniske 2000, Divon \& Fluhr 2006, Kemen \& Jones 2012).

\section{Relationships between hemibiotrophs and host plants}

In contrast to biotrophs, hemibiotrophs have dual life-styles. They first establish biotrophic relationships with their hosts and subsequently switch to necrotrophic relationships (Oliver \& Ipcho 2004, Divon \& Fluhr 2006, Krola et al. 2015). GAL4-like transcriptional activators in 
hemibiotrophs encoded by the CLTA1 gene are involved in reprogramming host cell metabolism and thereby switch the life-style from biotrophic to necrotrophic (Oliver \& Ipcho 2004, Krola et al. 2015). The initial biotrophic life-style of hemibiotrophs causes minimum damage to the plant tissues, while the fungus obtains nutrients from living plant tissues (Latijnhouwers et al. 2003). Most hemibiotrophs develop haustoria, whereas some produce intracellular hyphae to acquire nutrients from the host cytoplasm (Oliver \& Ipcho 2004, Divon \& Fluhr 2006). However, the hemibiotrophic life-style later breaks down host cell walls through secretion of cell wall degrading enzymes and the pathogen feeds on the released nutrients (Latijnhouwers et al. 2003, Kabbage et al. 2015). They also produce extracellular hyphae between the host cells to facilitate nutrient assimilation (Latijnhouwers et al. 2003, Oliver \& Ipcho 2004).

\section{Life cycle of biotrophs}

Biotrophs reproduce via asexual and/or sexual cycles, which includes host identification, spore adhesion, spore germination, penetration, colonization and sporulation (Panstruga 2003, Divon \& Fluhr 2006, Kemen \& Jones 2012). During spore germination and penetration, fungi use nutrients from the spore, such as glycogen and trehalose, and polyols such as mannitol, and lipids (Divon \& Fluhr 2006).

Biotrophs often enter the host via appressoria, which enable the fungus to penetrate through the epidermal cell wall (Latijnhouwers et al. 2003, Divon \& Fluhr 2006). An appressorium is a 'terminal dichotomous branching of hyphae growing on the host surface and consists of a pad of broad, multi-septate, short hyphae that are orientated perpendicular to the host surface to which they are attached by mucilage' (Hegedus \& Rimmer 2005). The mechanical strength of the appressorium is created by turgor pressure of glycerol via breakdown of internal stores of lipids and glycogen and also by the presence of melanin in appressorial cell walls (Latijnhouwers et al. 2003, Divon \& Fluhr 2006). After successful penetration in to the host plant, biotrophs live inside the intercellular space between leaf mesophyl cells and most are able to produce haustoria for the uptake of nutrients from the host (Divon \& Fluhr 2006, de Wit 2007).

Powdery mildew fungi superficially colonize the host and penetrate the leaf epidermis. They produce both asexual spores (conidia) and sexual spores (ascospores) (Spanu et al. 2012). Chains of conidia are produced on the leaf surface by epiphytic mycelium (Kemen \& Jones 2012). Conidia initially produce germ tubes and then appressoria to penetrate epidermal cells. (Micali et al. 2008, Kemen \& Jones 2012). Towards the end of the growing season powdery mildew pathogens produce ascocarps containing ascospores, which serve as dormant survival structures (Spanu et al. 2012).

One of the most well-studied biotrophic rust fungi is Puccinia graminis, which requires wheat as the main host and Berberis sp. as an alternate host to complete its life cycle (Spanu et al. 2012). Puccinia graminis produce asexual uredospores, which re-infect another wheat plant and thereby cause epidemics (Kemen \& Jones 2012). It also produces teliospores from the same pustules and these germinate to form short hyphae that give rise to basidiospores. Basidiospores are transported by wind to Berberis species (barberry), where they germinate, penetrate and colonize the leaves. The mycelium then produces sexual structures termed spermogonia. Spermogonia contain male sexual spores (spermatia) and female flexuous hyphae. Fertilization of female flexuous hyphae of one mating type by male sexual spores of the opposite mating type results in a diploid mycelium, which then forms aeciospores. The aeciospores can infect only cereal plants thus completing the life cycle (Heath 1997, Spanu et al. 2012, Huerta et al. 2015). All of these stages in the life cycle require the presence of a living host, either wheat or barberry.

\section{Life cycle of hemibiotrophs}

The hemibiotrophic life cycle involves an initial biotrophic phase and later a necrotrophic phase (Oliver \& Ipcho 2004, Divon \& Fluhr 2006). Colletotrichum lindemuthianum is a hemibiotrophic fungus on beans (common bean anthracnose) (Dufresne et al. 2000, Mendgen \& Hahn 2002, Munch et al. 2008, Souza et al. 2010). Conidia on the host surface germinate and form 
melanized appressoria that penetrate the epidermal cells (Mendgen \& Hahn 2002, Munch et al. 2008). The appressoria develop in to a primary penetration hypha, which is surrounded by the invaginated plant plasma membrane. The penetrated host cell remains alive with minimum damage during the biotrophic phase. During the necrotrophic phase the fungus secretes cell wall-degrading enzymes that break down the host cell wall. After a few days the plant cell membrane disintegrates and ultimately the host cell dies (Dufresne et al. 2000, Mendgen \& Hahn 2002). Thereafter the fungus grows as a necrotroph.

Another hemibiotroph is Moniliophthora roreri, which causes frosty pod rot on Theobroma sp. (Cacao) (Bailey et al. 2013). It produces meiospores, via meiosis, from the modified basidium (Evans 2007, Bailey et al. 2013). These spores are important as dispersal agents, for infection and survival (Evans 2007). Meiospores germinate and produce hyphae made up of haploid cells throughout the biotrophic phase. The necrotrophic phase is thought to start from the formation of dikaryotic hyphae and continues until sporulation on the pod surface (Griffith 2004, Evans 2007, Bailey et al. 2013, Meinhardt et al. 2014).

\section{How do biotrophs and hemibiotrophs overcome the host defenses?}

Plants have developed different mechanisms to combat pathogen defense (Gao et al. 2010, de Wit et al. 2012, Pandey et al. 2016). There are two types of response; systemic acquired resistance and induced systemic resistance (Gao et al. 2010). Systemic acquired resistance is mediated by salicylic acid and reactive oxygen species, which act against biotrophs (Gao et al. 2010, Guzman \& Heil 2014, Petriacq et al. 2016), whereas induced systemic resistance is mediated by jasmonic acid and ethylene signaling against necrotrophs (Guzman \& Heil 2014, Petriacq et al. 2016).

Jasmonic acid and salicylic acid act as key bioactive compounds that induce expression of phytochemicals involved in plant defenses (Howe 2004, Koo et al. 2009). Systemin and its precursor protein activate signaling cascade for biosynthesis of jasmonic acid upon necrotrophic invasion (Howe 2004, Koo et al. 2009). It has been shown that over-expression of jasmonic acid methyl transferase converts jasmonic acid to methyl jasmonic acid when Arabidopsis plants are infected with the necrotrophic Alternaria brassicicola (Penninckx et al. 1998, Seo et al. 2001). Methyl jasmonic acid triggers expression of Arabidopsis PDF1.2 gene that ultimately encodes an antifungal compound to block the pathogen (Penninckx et al. 1998, Seo et al. 2001). Plant antifungal compounds generally known as 'plant defensins' activate a signal transduction pathway leading to death of the fungus (Pandey et al. 2016). Salicylic acid dependent signaling pathway limits biotrophic colonization by activation of programmed cell death through a hypersensitive response (systemic acquired resistance). The programmed cell death is coupled with induction of phytoalexins, generation of reactive oxygen species (ROS) and pathogenesis related proteins, such as chitinases and glucanases. Plant chitinases are one of the main hydrolyzing enzymes that degrade fungal cell walls and limit colonization (Heath 1997, Govrin \& Levine 2000, Andrew et al. 2012, Guzman et al. 2014, Petriacq et al. 2016). Recent studies however, have shown that Jasmonic acid mediated signaling (JA-signaling) may be involved in grapevine resistance against biotrophic pathogens, such as powdery and downy mildews and mutants deficient in JA-signaling become susceptible to certain biotrophic fungal pathogens (Figueiredo et al. 2015).

Plants also have primary and secondary defense responses. Initially, pattern recognition receptors of the host plant recognize pathogen-associated molecular patterns (PAMPs) and thereby activate primary PAMP triggered defense responses (secretion of chitinases, glucanases and proteases, production of reactive oxygen species) to block the microbe (de Wit 2007, Dickman \& de Figueiredo 2011, Deeks et al. 2016, Pandey et al. 2016). Most pathogens are, however, able to overcome this primary defense response by producing effector proteins that interact with host plant targets and infect host plant tissue (de Wit 2007, Koeck et al. 2011, Kemen \& Jones 2012). Effector proteins are essential for microbe colonization. These molecules modulate plant defense responses and provide nutrients for microbes (Deeks et al. 2016). Some host plants produce resistance proteins that disrupt effector-mediated interactions with a host target by activating a secondary 
defense response (de Wit 2007, Koeck et al. 2011, Deeks et al. 2016). Thus, for a biotrophic lifestyle it is essential for the pathogen to suppress the plant defense mechanisms (Panstruga 2003, Munch et al. 2008).

Plant resistance responses (systemic acquired resistance and induced systemic resistance) and plant defense responses (primary and secondary) described above might act together upon pathogen invasion. Plants recognize pathogen-associated molecular patterns and generate an early burst of reactive oxygen species. This activates the salicylic acid mediated defense response, which leads to programmed cell death through a hypersensitive response in the infected host cells that kills biotrophs (Heath 1997, Govrin \& Levine 2000, Pandey et al. 2016, Petriacq et al. 2016). Salicylic acid mediated defense response is activated against Plectosphaerella cucumerina during the early biotrophic life-style and later P. cucumerina gains advantage of the dead cells and switches to a necrotrophic life-style (Petriacq et al. 2016). The host then activates a jasmonic acid mediated defense response against $P$. cucumerina (Petriacq et al. 2016).

Some fungi exhibit different strategies to overcome host plant defenses. The cell walls of germ tubes and appressoria contains chitin (Gueddari et al. 2002). Plants produce chitinases upon pathogen attack. Plant chitinase hydrolyses chitin and disintegrates cell wall components into polymers that can act as elicitors to initiate plant defense responses (Gueddari et al. 2002, Munch et al. 2008). However, some fungi are able to modify their cell wall by converting chitin to chitosan by chitin de- $N$-acetylases (Gueddari et al. 2002). Colletotrichum graminicola (maize anthracnose), Puccinia graminis (wheat stem rust) and Uromyces fabae (maize anthracnose) are able to mask exposed chitin and protect cell walls of pathogenic hyphae from enzymatic hydrolysis by host chitinases (Munch et al. 2008). Cladosporium fulvum employs another strategy to avoid chitin degradation. It produces Avr4 proteins (effectors), which have a chitin binding domain. Avr4 is able to bind and shield fungal cell wall chitin (Munch et al. 2008, Horbach et al. 2011, Koeck et al. 2011, de Wit et al. 2012). Recent studies have been found that Avr4 is also found in most members of Dothideomycetes (Koeck et al. 2011, de Wit et al. 2012).

\section{Co-evolution of biotrophs, hemibiotrophs and hosts}

Plants have co-evolved with fungi in natural ecosystems and agricultural systems over millions of years starting from early colonization of land by terrestrial plants (de Wit 2007, Hardoim et al. 2015, Kabbage et al. 2015). However, the co-evolution of plants and natural continuum of fungal life-styles (switching fungal life-style from biotrophy to necrotrophy and to saprotrophy) has not been well-characterized.

It is believed that the last eukaryotic common ancestor gave rise to two clades, Opisthokonts and Stramenopiles 1500 million years ago. Fungi and animals evolved from Opisthokonts $1000-1500$ million years ago, whereas oomycetes evolved with diatoms and brown algae from Stramenopiles 700 - 1000 million years ago (Kemen \& Jones 2012). The fungi then differentiated in to three lineages, Glomeromycota, Ascomycota and Basidiomycota, 450 - 850 million years ago. Fungi are thought to have colonized terrestrial plants about 450 million years ago (Kemen \& Jones 2012, Kabbage et al. 2015). Biotrophic fungi are found in two kingdoms (Stramenopila and Fungi) and two major fungal phyla (Ascomycota and Basidiomycota) suggesting convergent evolution of biotrophy through different evolutionary lineages (Spanu et al. 2010). The oldest known fossil record of fungi (460 million years old) shows similar properties with arbuscular mycorrhizal fungi (AMF) (Hardoim et al. 2015). It is assumed that AMF evolved biotrophic lifestyle with bryophyte-like early land plants (Hardoim et al. 2015). It has been suggested that the initial fungal colonization of host plants was a biotrophic life style with the ability to modulate plant defenses, conversely the development of hydrolytic enzymes and phytotoxins gave rise to hemibiotrophy and saprotrophy through convergent and divergent evolution (Kemen \& Jones 2012, Spanu et al. 2012, Delaye et al. 2013, Hardoim et al. 2015, Kabbage et al. 2015).

Plants have faced high selection pressure to detect and suppress pathogenic fungi (Kemen \& Jones 2012). Pathogenic fungi have also faced high selection pressures by plant defense systems during colonization inside plant tissues (Kemen \& Jones 2012). This antagonistic interaction of 
plant defense and pathogen virulence leads to a continuous evolutionary arms race between plants and fungi (Kemen \& Jones 2012).

Current genome sequencing techniques reveals that the biotroph, Blumeria graminis (powdery mildew on barley) has a larger genome size than necrotrophic and saprotrophic fungi (Kemen \& Jones 2012). The genome expansion of biotrophs is due to increased transposable elements (Kemen \& Jones 2012, Spanu et al. 2010, 2012). Transposable elements enable fast genome re-organization (recombination) and increase genetic variation that evolves a better compatibility with the host plant (Spanu et al. 2010). Effector genes are also found within transposable elements in the genome of the oomycete Phytophthora infestans (Kemen \& Jones 2012, Spanu et al. 2012). Biotrophy has also lost genes that are essential for the biosynthesis of certain metabolites and pathogenicity factors. These are considered as common genomic hallmarks associated with biotrophy (Spanu et al. 2010). This would also be one of the explanations for rapid adaptation of biotrophs and hemibiotrophs with their host plant.

\section{Conclusion}

Most fungi exhibit a continuum of life-styles from biotrophy, through to necrotrophy, and ultimately to saprotrophy, making it difficult to draw boundaries between the different life-styles. Different criteria have been used to classify fungal life-styles, such as nutrient source, development of special morphological structures for nutrient assimilation and more recently, types of defense mechanism (jasmonate vs. salicylic acid pathway) used against the host plant. Some fungi exhibit a biotrophic life-style for their entire life cycle whereas others change their life-style depending on the environment. Therefore it is often hard to classify their life mode accurately. Thus, there has been confusion in classifying a particular fungus under a life-style and the definitions presented in this paper may help to clarify life-styles in the future. Cytological and molecular studies may also provide deep understanding of fungal life-styles.

\section{Acknowledgements}

We would like to thank the Mushroom Research Foundation, Chiang Rai, for providing Nimali de Silva with a scholarship to study towards a PhD. Sc.D. Igor Maksimov (Institute of Biochemistry and Genetics, Russian Academy of Sciences, Ufa, Russia) is acknowledged for his valuable advice. Nimali de Silva thanks Samantha C. Karunarathna, Dhanushka N. Wanasinghe, Ishani Goonasekara, R. Phookamsak and Danushka Tennakoon for their valuable suggestions and help.

\section{References}

Andrew M, Barua R, Short SM, Kohn LM. 2012 - Evidence for a common toolbox based on necrotrophy in a fungal lineage spanning necrotrophs, biotrophs, endophytes, host generalists and specialists. PLOS One 7, 1-14

Ariyawansa HA, Thambugala KM, Manamgoda DS, Jayawardena R, Camporesi E, Boonmee S, Wanasinghe DN, Norphanphoun C, Phookamsak R, Hongsanan S, Singtripop C, Chukeatirote E, Kang JC, Jones EBG, Hyde KD. 2015 - Towards a natural classification and backbone tree for Pleosporaceae. Fungal Diversity 71, 85-139

Bailey BA, Crozier J, Sicher RC, Strem MD, Melnick R, Carazzolle MF, Costa GGL, Pereira GAG, Zhang D, Maximova S, Guiltinan M, Meinhardt L. 2013 - Dynamic changes in pod and fungal physiology associated with the shift from biotrophy to necrotrophy during the infection of Theobroma cacao by Moniliophthora roreri. Physiological and Molecular Plant Pathology 81, 84-96

Barr ME. 1987 - Prodromus to class Loculoascomycetes. University of Massachusetts, Amherst

Both M, Csukai M, Stumpf MPH, Spanu PD. 2005 - Gene expression profiles of Blumeria graminis indicate dynamic changes to primary metabolism during development of an obligate biotrophic pathogen. The Plant Cell 17, 2107-2122 
Dada OL and Lucas JA. 2007 - Localized hemibiotrophy in Colletotrichum cytological and molecular taxonomic similarities among $C$. destructivum $C$. linicola and $C$. truncatum. Plant Pathology 56, 437-447

Damm U, O'Connell RJ, Groenewald JZ, Crous PW. 2014 - The Colletotrichum destructivum species complex - hemibiotrophic pathogens of forage and field crops. Studies in Mycology 79, 49-84

de Wit PJGM. 2007 - Visions and reflections. How plants recognize pathogens and defend themselves. Cellular and Molecular Life Sciences 64, 2726-2732

de Wit PJGM, Burgt AVD, Kmen BO, Stergiopoulos I, Abd-Elsalam K, Aert AL, Bahkali AH, Beenen HG, Chettri P, Cox MP, Datema E, de Vries R, Dhillon B, Ganley AR, Griffiths SA, Guo Y, Hamelin RC, Henrissat B, Kabir MS, Jashni MK, Kema G, Klaubauf S, Lapidus A, Levasseur A, Lindquist E, Mehrabi R, Ohm RA, Owen TJ, Salamov A, Schwelm A, Schijlen E, Sun H, Burg HAVD, van Ham RCHJ, Zhang S, Goodwin SB, Grigoriev IV, Collemare J, Bradshaw RE. 2012 - The genomes of the fungal plant pathogens Cladosporium fulvum and Dothistroma septosporum reveal adaptation to different hosts and life-styles but also signatures of common ancestry. PLOS Genetics 8, 1-22

Deeks M and Rodriguez CS. 2016 - Seeing is believing: cell biology at the plant-microbe interface. New Phytologist 211, 16-19

Delaye L, Guzmán GG, Heil M. 2013 - Endophytes versus biotrophic and necrotrophic pathogens are fungal life-styles evolutionarily stable traits? Fungal Diversity 60, 125-135

Dickman MB and de Figueiredo P. 2011 - Comparative pathobiology of fungal pathogens of plants and animals. PLOS Pathogens 7, 177-184

Dissanayake AJ, Liu M, Zhang W, Chen Z, Udayanga D, Chukeatirote E, Li X, Yan JY, Hyde KD. 2015 - Morphological and molecular characterization of Diaporthe species associated with grapevine trunk disease in China. Fungal Biology 119, 283-294

Divon HH, Fluhr R. 2006 - Nutrition acquisition strategies during fungal infection of plants. Federation of European Microbiological Societies, Blackwell Publishing Ltd.

Dufresne M, Perfect S, Pellier AL, Bailey JA, Langin T. 2000 - Colletotrichum lindemuthianum on common bean. The Plant Cell 12, 1579-1589

Evans HC. 2007 - Cacao diseases - the trilogy revisited. Phytopathology 97, 1640-1643

Figueiredo A, Monteiro F, Sebastiana M. 2015 - First clues on a jasmonic acid role in grapevine resistance against the biotrophic fungus Plasmopara viticola. European Journal of Plant Pathology 142, 645-652

Gao FK, Dai CC, Liu XZ. 2010 - Mechanism of fungal endophytes in plant protection against pathogens. African Journal of Microbiology Research 4, 1346-1351

Govrin EM and Levine A. 2000 - The hypersensitive response facilitates plant infection by the necrotrophic pathogen Botrytis cinerea. Current Biology 10, 751-757

Griffith GW. 2004 - Witches' brooms and frosty pods: threats to world cacao production. Biologist $51,71-75$

Gross A, Holdenrieder O, Pautasso M, Queloz V, Sieber TN. 2014 - Hymenoscyphus pseudoalbidus, the causal agent of European ash dieback. Molecular Plant Pathology 15, 5-21

Gueddari NEE, Rauchhaus U, Moerschbacher BM, Deising H. 2002 - Developmentally regulated conversion of surface-exposed chitin to chitosan in cell walls of plant pathogenic fungi. New Phytologist 156, 103-112

Guzman GG and Heil M. 2014 - Life histories of hosts and pathogens predict patterns in tropical fungal plant diseases. New Phytologist 201, 1106-1120

Hardoim PR, Overbeek LSV, Berg G, Pirttila AM, Compant S, Campisano A, Doring M, Sessitsch A. 2015 - The hidden world within plants: ecological and evolutionary considerations for defining functioning of microbial endophytes. Microbiology and Molecular Biology Reviews 79, 293-320

Harrison MJ. 1999 - Biotrophic interfaces and nutrient transport in plant/fungal symbioses. Journal of Experimental Botany 50, 1013-1022 
Heath MC. 1997 - Signaling between pathogenic rust fungi and resistant or susceptible host plants. Annals of Botany 80, 713-720

Hegedus DD and Rimmer SR. 2005 - Sclerotinia sclerotiorum: When to be or not to be a pathogen? FEMS Microbiology Letters 251, 177-184

Horbach R, Quesada ARN, Knogge W, Deising HB. 2011 - When and how to kill a plant cell: infection strategies of plant pathogenic fungi. Journal of Plant Physiology 168, 51-62

Howe GA. 2004 - Jasmonates as signals in the wound response. Journal of Plant Growth Regulation 23, 223-237

Huerta EJ, Singh RP, Roelfs AP. 2015 - Rusts fungi of wheat. CRC Press, Taylor \& Francis Group Hyde KD and Soytong K. 2008 - The fungal endophyte dilemma. Fungal Diversity 33, 163-173

Hyde KD, Jones EBG, Liu JK, Ariyawansa H, Boehm E, Boonmee S, Braun U, Chomnunti P, Crous PW, Dai DQ, Diederich P, Dissanayake A, Doilom M, Doveri F, Hongsanan S, Jayawardena R, Lawrey JD, Li YM, Liu YX, Lücking R, Monkai J, Muggia L, Nelsen MP, Pang KL, Phookamsak R, Senanayake IC, Shearer CA, Suetrong S, Tanaka K, Thambugala KM, Wijayawardene NN, Wikee S, Wu HX, Zhang Y, Hudson BA, Alias SA, Aptroot A, Bahkali A, Bezerra JL, Bhat DJ, Camporesi E, Chukeatirote E, Gueidan C, Hawksworth DL, Hirayama K, Hoog SD, Kang JC, Knudsen K, Li WJ, Li XH, ZY, Mapook A, McKenzie EHC, Miller AN, Mortimer PE, Phillips AJL, Raja HA, Scheuer C, Schumm F, Taylor JE, Tian Q, Tibpromma S, Wanasinghe DN, Wang Y, Xu JC, Yacharoen S, Yan JY, Zhang M. 2013 - Families of dothideomycetes. Fungal Diversity 63, 1-313

Kabbage M, Yarden O, Dickman MB. 2015 - Pathogenic attributes of Sclerotinia sclerotiorum: switching from a biotrophic to necrotrophic lifestyle. Plant Science 233, 53-60

Kankanala P, Czymmek K, Valen B. 2007 - Roles for rice membrane dynamics and plasmodesmata during biotrophic invasion by the blast fungus. The Plant Cell 19, 706-724

Kemen E and Jones JDG. 2012 - Obligate biotroph parasitism: can we link genomes to life-styles? Trends in Plant Science 17, 448-457

Kirk PM, Cannon PF, David JC, Stalpers JA. 2001 - The Dictionary of the Fungi. $9^{\text {th }}$ edition, CABI Bioscience, CAB International, Biddles Ltd, Great Britain

Koeck M, Hardham AR, Dodds PN. 2011 - The role of effectors of biotrophic and hemibiotrophic fungi in infection. Cell Microbiology 13, 1849-1857

Koo AJK, Gao X, Jones AD, Howe GA. 2009 - A rapid wound signal activates the systemic synthesis of bioactive jasmonates in Arabidopsis. The Plant Journal 59, 974-986

Krola P, Igielski R, Pollmannb S, Kepczynska EK. 2015 - Priming of seeds with methyl jasmonate induced resistance to hemi-biotroph Fusarium oxysporum f.sp. lycopersici in tomato via 12oxo-phytodienoic acid, salicylic acid, and flavonol accumulation. Journal of Plant Physiology $179,122-132$

Latijnhouwers M, de Wit PJGM, Govers F. 2003 - Oomycetes and fungi: similar weaponry to attack plants. Trends in Microbiology 11, 462-469

Liu JK, Hyde KD, Jones EBG, Ariyawansa HA, Bhat DJ, Boonmee S, Maharachchikumbura SSN, McKenzie EHC, Phookamsak R, Phukhamsakda C, Shenoy BD, Wahab AA, Buyck B, Chen J, Chethana KWT, Singtripop C, Dai DQ, Dai YC, Daranagama DA, Dissanayake AJ, Doilom M, D'souza MJ, Fan XL, Goonasekara ID, Hirayama K, Hongsanan S, Jayasiri SC, Jayawardena RS, Karunarathna SC, Li WJ, Mapook A, Norphanphoun C, Pang KL, Perera RH, Persoh D, Pinruan U, Senanayake IC, Somrithipol S, Suetrong S, Tanaka K, Thambugala KM, Tian Q, Tibpromma S, Udayanga D, Wijayawardene NN, Wanasinghe D, Wisitrassameewong K, Zeng XY, Abdel-Aziz FA, Adamcik S, Bahkali AH, Boonyuen N, Bulgakov T, Callac P, Chomnunti P, Greiner K, Hashimoto A, Hofstetter V, Kang JC, Lewis D, Li XH, Liu XZ, Matsumura M, Mortimer PE, Rambold GR, Randrianjohany E, Sato G, Indrasutdhi VS, Tian CM, Verbeken A, Brackel WV, Wang Y, ChiWen T, Xu JC, Yan JY, Zhao RL, Camporesi E. 2015 - Fungal diversity notes 1-110: taxonomic and phylogenetic contributions to fungal species. Fungal Diversity 75, 27-274

Meadows R. 2011 - Why biotrophs can't live alone. PLOS Pathogens 9, 1-2 
Meinhardt LW, Costa GGL, Thomazella DPT, Teixeira PJPL, Carazzolle MF, Schuster SC, Carlson JE, Guiltinan MJ, Mieczkowski P, Farmer A, Ramaraj T, Crozier J, Davis RE, Shao J, Melnick RL, Pereira GAG, Bailey BA. 2014 - Genome and secretome analysis of the hemibiotrophic fungal pathogen, Moniliophthora roreri, which causes frosty pod rot disease of cacao: mechanisms of the biotrophic and necrotrophic phases. BioMed Central Genomics $15,164-189$

Mendgen K and Hahn M. 2002 - Plant infection and the establishment of fungal biotrophy. Trends in Plant Science 7, 352-356

Micali C, Gollner K, Humphry M, Consonni C, Panstruga R. 2008 - The powdery mildew disease of Arabidopsis: a paradigm for the interaction between plants and biotrophic fungi. The Arabidopsis Book, American Society of Plant Biologists 1-19

Munch S, Lingner U, Floss DS, Ludwig N, Sauer N, Deising HB. 2008 - The hemibiotrophic lifestyle of Colletotrichum species. Journal of Plant Physiology 165, 41-51

O'Hanlon KA, Knorr K, Jorgensen LN, Nicolaisen M, Boelt B. 2012 - Exploring the potential of symbiotic fungal endophytes in cereal disease suppression. Biological Control 63, 69-78

Oliver RP and Ipcho SVS. 2004 - Arabidopsis pathology breathes new life into the necrotrophsvs.-biotrophs classification of fungal pathogens. Molecular Plant Pathology 5, 347-352

Pandey D, Rajendran SRCK, Sajeesh MGPK, Kumar A. 2016 - Plant defense signaling and responses against necrotrophic fungal pathogens. Journal of Plant Growth Regulation 35, 116

Panstruga R. 2003 - Establishing compatibility between plants and obligate biotrophic pathogens. Current Opinion in Plant Biology 6, 320-326

Parniske M. 2000 - Intracellular accommodation of microbes by plants: a common developmental program for symbiosis and disease? Current Opinion in Plant Biology 3, 320-328

Penninckx IAMA, Thomma BPHJ, Buchala A, Métraux JP, Broekaert WF. 1998 - Concomitant activation of jasmonate and ethylene response pathways is required for induction of a plant defensin gene in Arabidopsis. The Plant Cell 10, 2103-2113

Petriacq P, Stassen JHM, Ton J. 2016 - Spore density determines infection strategy by the plant pathogenic fungus Plectosphaerella cucumerina. Plant Physiology, American Society of Plant Biologists

Petrini O, Sieber TN, Toti L, Viret O. 1992 - Ecology, metabolite production, and substrate utilization in endophytic fungi. Natural Toxins 1, 185-196

Plant Pathology Glossary 2003 - http://bugs.bio.usyd.edu.au/learning/resources

Porras-Alfaro A and Bayman P. 2011 - Hidden fungi, emergent properties: endophytes and microbiomes. The Annual Review of Phytopathology 49, 291-315

Promputtha I, Jeewon R, Lumyong S, McKenzie EHC, Hyde KD. 2005 - Ribosomal DNA fingerprinting in the identification of non sporulating endophytes from Magnolia liliifera (Magnoliaceae). Fungal Diversity 20, 167-186

Promputtha I, Lumyong S, Dhanasekaran V, McKenzie EHC, Hyde KD, Jeewon R. 2007 - A phylogenetic evaluation of whether endophytes become saprotrophs at host senescence. Microbial Ecology 53, 579-590

Seo HS, Song JT, Cheong JJ, Lee YH, Lee YW, Hwang I, Lee JS, Choi YD. 2001 - Jasmonic acid carboxyl methyltransferase: a key enzyme for jasmonate-regulated plant responses. PNAS 98, 4788-4793

Souza EA, Camargo Junior OA, Pinto JMA. 2010 - Sexual recombination in Colletotrichum lindemuthianum occurs on a fine scale. Genetics and Molecular Research 9, 1759-1769

Spagnolo A, Larignon P, Robert MM, Hovasse A. 2014 - Flowering as the most highly sensitive period of grapevine (Vitis vinifera L. cv Mourvedre) to the Botryosphaeria dieback agents Neofusicoccum parvum and Diplodia seriata infection. International Journal of Molecular Sciences 15, 9644-9669

Spanu PD, Abbott JC, Amselem J, Burgis A, Soanes DM, Stüber K, Themaat EVLV, Brown JKM, Butcher SA, Gurr SJ, Lebrun MH, Ridout CJ, Lefert PS, Talbot NJ, Ahmadinejad N, Ametz 
C, Barton GR, Benjdia M, Bidzinski P, Bindschedler LV, Both M, Brewer MT, Davidson LC, Davidson MMC, Collemare J, Cramer R, Frenkel O, Godfrey O, Harriman J, Hoede C, King BC, Klages S, Kleemann J, Knoll D, Koti PS, Kreplak J, López-Ruiz FJ, Lu X, Maekawa T, Mahanil S, Micali C, . Milgroom MG, Montana G, Noir S, O’Connell RJ, Oberhaensli S, Parlange F, Pedersen C, Quesneville H, Reinhardt R, Rott M, Sacristán S, Schmidt SM, Schön M, Skamnioti P, Sommer H, Stephens A, Takahara H, Christensen HT, Vigouroux M, WeBling R, Wicker T, Panstruga R. 2010 - Genome expansion and gene loss in powdery mildew fungi reveal tradeoffs in extreme parasitism. Science 330, 1543-1545

Spanu PD. 2012 - The genomics of obligate (and nonobligate) biotrophs. The Annual Review of Phytopathology 50, 91-109

Torres JRU, Adams P, Kamas J, Gubler WD. 2009 - Identification, incidence, and pathogenicity of fungal species associated with grapevine dieback in Texas. American Journal of Enology and Viticulture 60, 497-507

Wang X, Jiang N, Liu J, Liu W, Wang GL. 2014 - The role of effectors and host immunity in plant-necrotrophic fungal interactions. Virulence 5, 722-732

Wiktionary 2016 - https://en.wiktionary.org/wiki/hemibiotroph

Xu C, Wang C, Ju L, Zhang R, Biggs AR, Tanaka E, Li B, Sun G. 2015- Multiple locus genealogies and phenotypic characters reappraise the causal agents of apple ring rot in China. Fungal Diversity 71, 215-231

Yan JF, Broughton SJ, Yang SL, Gange AC. 2015 - Do endophytic fungi grow through their hosts systemically? Fungal Ecology 13, 53-59

Yan JY, Jayawardena MMRS, Goonasekara ID, Wang Y, Zhang W, Liu M, Huang JB, Wang ZY, Shang JJ, Peng YL, Bahkali A, Hyde KD, Li XH. 2015 - Diverse species of Colletotrichum associated with grapevine anthracnose in China. Fungal Diversity 71, 233-246 